\begin{tabular}{|c|c|c|}
\hline 前田 & 学 ${ }^{11}$ ・西岡 & 慶子 ${ }^{12}$ ・内藤 好宏 ${ }^{11}$ \\
\hline 綾田 & 展明1)・増田 & 游1) • 川崎康一郎 ${ }^{2}$ \\
\hline 赤木 & 成子3)・栗田 & 宣子3) ・水河 幸夫33 \\
\hline 小河 & 原利彰 & 敬三 ${ }^{4)}$ - 長谷川英夫 ${ }^{5)}$ \\
\hline
\end{tabular}

\title{
Clinical Effect of Azelastine Hydrochloride in Allergic Rhinitis
}

\author{
Manabu Maeta, Keiko Nishioka, Yoshihiro Naito \\ (Okayama University Medical School), et al
}

\begin{abstract}
Sixty-six patients with perennial allergic rhinitis were treated with azelastine hydrochloride.

Based on the global improvement, two weeks after the beginning of the treatment, "moderate improvement or better" was observed in $42 \%$ of the patients, and "slight improvement or better" in 79\%, and four weeks after, "moderate improvement or better" was observed in 55\% of the patients, and "slight improvement or better" in $89 \%$. On the records of diary for allergic rhinitis, sneezing, nasal discharge and nasal obstruction were improved in all patients.

These results indicate that azelastine hydrochloride is highly effective in the treatment of perennial allergic rhinitis.
\end{abstract}

Key words: azelastine hydrochloride, allergic rhinitis, diary for allergic rhinitis

緒言

塩酸アゼラスチンは図 1 に示されるような化 学構造を有しており，フタラゾン誘導体の中で あ特に強い抗アレルギー活性と持続性を特徽之 する化合物である.
今回我々は66例の鼻アレルギー患者に対して この抗アレルギー剂である塩酸アゼラスチンを 投与し，主としてその臨床効果について統計 学的な検討を行い若干の知見を得たので報告 した.

1) 岡山大学医学部耳鼻咽喉科学教室

2）川崎医科大学附属川崎病院耳鼻咽喉科

3）岡山赤十字病院耳鼻咽喉科

4) 国立岡山病院耳鼻咽喉科

5）姫路聖マリア病院耳鼻咽喉科

6）府中総合病院耳鼻咽喉科 


\section{対象および方法}

\section{1. 対 象}

昭和 62 年 1 月から 11 月までの 11 力間に，各 施設を受部した患者のうち三主徴, 局所所見, 皮膚テスト，誘発テスト，RAST 法その他のア レルギーテストからアレルゲンの確定した通年 性鼻アレルギー患者を対象とした。な打年踰は 6 歳以上, 症状が中等症以上のものを対象とし た。 また以下の項目に該当する患者は対象から 除外した.

1）重症の慢性副鼻腔炎，肥厚性鼻炎を併発 している患者.

2 ）妊婦および妊娠している可能性のある患 者.

3 ）現在減感作療法を施行している患者.

4 ）その他, 担当医が本調査に不適当とする 患者.

\section{2. 投与方法}

塩酸アゼラスチン（アゼプチン®）を 1 錠中 に $1 \mathrm{mg}$ 含有する錠剂を用い，1 回 1 錠 $(1 \mathrm{mg})$, 朝, 就寝時の 1 日 2 回内服させ，投与期間は原 則として 4 週間とした。

なお，DSCG，トラニラスト，フマル酸ケト チフェンなどの抗アレルギー剤は併用禁止と し，次の薬剤は試験薬剤の効果に影響を与える と考えられることから，なるべく併用を避ける こととした，止むを得ず使用する場合は調査表 の併用薬の欄に 1 週間毎の薬剤名と数量を記入

一般名 : 塩酸アゼラスチン (Azelastine hydrochloride) 化学名 : (土)-4-(4-chlorobenzyl)-2-(hexahydro-1methyl- $1 \boldsymbol{H}$-azepin-4-yl)- $1(2 \boldsymbol{H})-$ phthalazinone hydrochloride

分子式 : $\mathrm{C}_{22} \mathrm{H}_{24} \mathrm{CIN}_{3} \mathrm{O} \cdot \mathrm{HCl}$

分子量 : 418.37

構造式 :

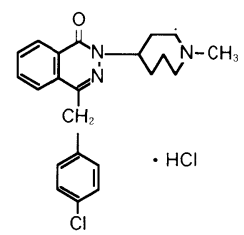

図 1
した.

$$
\begin{aligned}
& \text { ・ステロイド剤・血管収縮剤 } \\
& \text { ・ } \gamma \text {-グロブリン剂・・降圧剂 } \\
& \text { ・抗ヒスタミン剂・・精神安定剂 }
\end{aligned}
$$

来院時ネブライザーの適用は可，ステロイド （ベクロメタゾン）の噴霧剤を止むを得ず使用 することは可とした.

3. 試験スケジュールと調査項目

1 週間の導入期間は原則として併用禁止薬の 使用を中止し，その後 4 週間を投薬期間，さら に $1 〜 2$ 週間を追跡期間とした.

下記の項目について図 2 に示すスケジュール に従って実施した.

1) 患者背景 : 試験開始時に患者の病型, 好 発期, 重症度, 主抗原, 併発疾患, アトピー性 疾患既往歴などについて調査し，調査表に記入 した，重症度は原則として，表 1 亿示す奥田の 基準1 に従って判定した.

2）自覚症状および他覚的所見：投与開始直 前と投与後 2 週間目および 4 週間目に自覚症状 （くしゃみ発作，鼻汁，鼻閉，嗅覚異常，日常 生活の支障度), 他覚的所見 (下甲介粘膜の腫 脹, 下甲介粘膜の色調, 鼻汁量, 鼻汁の性状, 可能であれば鼻汁中好酸球数）およびその他の

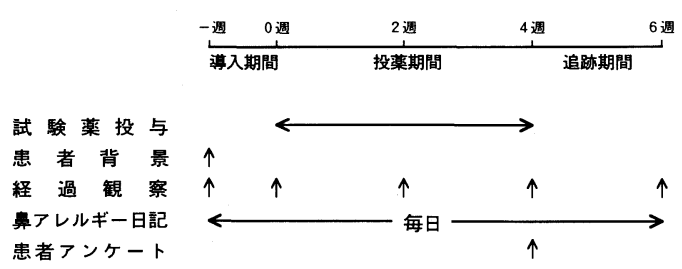

\begin{tabular}{|c|c|c|c|c|c|}
\hline \multirow{2}{*}{\multicolumn{2}{|c|}{$\begin{array}{l}\text { 程度および } \\
\text { 重 症 度 }\end{array}$}} & \multicolumn{4}{|c|}{ くしゃみ発作または鼻斗 } \\
\hline & & m & $H$ & + & - \\
\hline \multirow{2}{*}{ 鼻 } & H & 重 & 重 & 重 & 重 \\
\hline & H & 重 & 中 & 中 & 中 \\
\hline \multirow[t]{2}{*}{ 閉 } & + & 重 & 中 & 軽 & 軽 \\
\hline & - & 重 & 中 & 軽 & 無 \\
\hline
\end{tabular}

図 2 試験スケジュール

表 1 重症度の分類 
随伴症状について観察を行い，それぞれの程度 を表 2 ，表 3 亿示す奥田の基準 ${ }^{1)}$ 亿従って判定 し調査表に記入した。

3）鼻アレルギー日記，患者アンケート：試 験開始時より終了まで患者に所定の鼻アレルギ 一日記を配布し，くしゃみ (発作回数)，鼻汁 (擤鼻回数)，鼻閉 $(-,+,+,+\#)$ について 毎日記録させた，鼻閉については，(一)つまら ない，(+)息がしにくくはないが少し鼻がつま る，（十）鼻がつまって息がしにくい，（州）鼻 がつまって息ができない，とした。 また，投与 終了後に患者アンケートを配布し，薬剂の効果 に対する印象を記入させた。

4. 判 定

1）自覚症状および他覚的所見の改善度 : 調 査表に記入された各症状，所見の程度に基づい て投与後 2 週間目， 4 週間目に投与前の状態之 比較し総括的に判定した。

2）全般改善度: 投与後 2 週間目， 4 週間目
に，自覚症状および他覚的所見の改善，鼻アレ ルギー日記，患者アンケートを総括して全般的 な改善について判定した。

3）副作用：試験期間中の随伴症状および諸 検査により副作用の有無を判定した.

4) 有用度：全般改善度に副作用等を考慮し て判定した

5）鼻アレルギー日記における自覚症状の点 数化による改善度 : 鼻アレルギー日記に記録さ れた各症状について，くしゃみ（発作回数）之 鼻汁（擤鼻回数）は実際の回数，鼻閉は $(+)$ につき 1 点の点数を与え 1 週間毎に集計し， 1 日の平均值を算出し，投与前および投与期間中 の推移を比較検討した.

1. 患者背景

\section{結果}

対象は通年性鼻アレルギーの外来患者66例 で，その背景を表 4 に示した. 平均年齡31.5歳， 男28例（平均年齢26.6歳），女38例（平均年齢

表 2 自覚症状の程度

\begin{tabular}{|c|c|c|c|c|c|}
\hline 種 類 程 度 & HI & H & + & & \\
\hline $\begin{array}{l}<し ょ \text { み発作 } \\
\text { (1日の発作回数) }\end{array}$ & 10回以上 & $9 \sim 5$ 回 & 4 回以下 & & \\
\hline 鼻 1 日の擤鼻回数 $)^{\text {计 }}$ & 10回以上 & $9 \sim 5$ 回 & 4 回以下 & & \\
\hline 鼻 & 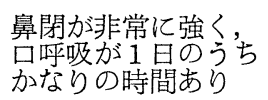 & $\begin{array}{l}\text { 鼻閉が強く, 口呼吸 } \\
\text { り11日うち時々あ }\end{array}$ & $\begin{array}{l}\text { 口呼吸は全くないが } \\
\text { 鼻閉あり }\end{array}$ & な & し \\
\hline 嗅 覚 の 異 常 & 嗅覚脱失 & 臭うが弱い & 少し弱い & 正 & 常 \\
\hline 日常生活の支障度 & 仕事が手につかない & $(H+H) と(+)$ の中間 & $\begin{array}{l}\text { 仕事にあまり支障が } \\
\text { ない }\end{array}$ & な & し \\
\hline
\end{tabular}

表 3 他覚的所見の程度

\begin{tabular}{|c|c|c|c|c|c|}
\hline 種 類 程 度 & m & H & + & \multicolumn{2}{|c|}{-} \\
\hline 下甲介粘膜の腫脹 & 中甲介みえず & $(\mathrm{H})$ と $(+)$ の中間 & 中甲介中央まで & な & し \\
\hline 下甲介粘膜の色調 & 白 & 赤 & 薄 赤 & 正 & 常 \\
\hline 鼻＜wide>汁 & 充 & $(\mathrm{HH})$ と $(+)$ の中間 & 附着程度 & な & し \\
\hline 鼻 汁 の 性 状 & 水 & 粘 性 & 膿 & な & し \\
\hline 鼻汁中好酸球数 & 群 & $(\mathrm{H})$ と (+) の中間 & 弱拡でめだつ程度 & & \\
\hline
\end{tabular}


35.2歳）であった。病型は鼻汁型が38例（57.6

\%)で最む多かった。重症度は重症25例（37.9 $\%)$, 中等症 36 例 $(54.5 \%)$ であった. 主抗原の 大半は八ゥスダストとダニであった。

2. 自覚症状拈よび他覚的所見の改善度

自覚症状および他覚的所見の総括判定を表 5 に示した．自覚症状では，投与後 2 週間目で， 良い以上 $40.9 \%$ ，やや良い以上 $75.8 \%$ ，投与後 4 週間目で，良い以上 $59.1 \%$ ，やや良い以上 $87.9 \%$ であった．他覚的所見では，投与後 2 週

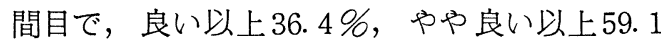
$\%$ ，投与後 4 週間目で，良い以上 $51.5 \%$ ，やや 良い以上 $74.2 \%$ あった。

3. 全般改善度

表 5 に示すように，投与後 2 週間目で，中等 度改善以上 $42.2 \%$ ，軽度改善以上 $78.8 \%$ ，投与 後 4 週間目で，中等度改善以上 $54.5 \%$ ，軽度改
善以上 $89.4 \%$

4. 副作用

全症例において自覚的あるいは他覚的副作用 は全く認められなかった。

5. 有用度

投与後 2 週間目で，有用以上 $37.9 \%$ ，やや有 用以上 $78.8 \%$ ，投与後 4 週間目で，有用以上 $37.6 \%$ ，やや有用以上 $90.9 \%$ あった（表 5 ).

6. 鼻アレルギー日記における自覚症状の 改善

図 3 に鼻アレルギー日記から集計した，くし やみ，鼻汁，鼻閉の 1 日平均值の推移を 1 週間 毎に示した. 投与前と投与後各週の効果に関し $て \mathrm{t}$ 検定を行った。 くしゃみ発作回数は投与後 1 週間目より減少し投与後 2 週間目と 3 週間目 では投与前との間に有意差 $(p<0.05)$ が認めら れた。擤鼻回数は投与後 1 週間目より減少し投

表 4 患者背景

\begin{tabular}{|c|c|c|c|}
\hline & 背 景 因 子 & 例 数 & 比率 $(\%)$ \\
\hline & 総 症 例 数 & 66 & \\
\hline \multirow{2}{*}{ 性 } & 男 & 28 & 42.4 \\
\hline & 女 & 38 & 57.6 \\
\hline \multirow[t]{2}{*}{ 年 } & $\sim 19$ & 16 & 24.2 \\
\hline & $20 \sim 39$ & 33 & 50.0 \\
\hline \multirow[b]{2}{*}{ 齢 } & $40 \sim 59$ & 13 & 19.7 \\
\hline & $60 \sim$ & 4 & 6.1 \\
\hline \multirow{3}{*}{ 病 } & くしゃみ 型 & 15 & 22.7 \\
\hline & 鼻 汁 型 & 38 & 57.6 \\
\hline & 鼻 閉 型 & 20 & 30.3 \\
\hline 型 & くしゃみ・鼻閉型 & 19 & 28.8 \\
\hline \multirow{3}{*}{ 好 } & \multirow{2}{*}{$\begin{array}{l}\text { 有 } \\
\text { 無 }\end{array}$} & 28 & 42.4 \\
\hline & & 37 & 56.1 \\
\hline & 記 載 な & 1 & 1.5 \\
\hline 発 & 春 & 21 & 31.8 \\
\hline 期 & 夏 & 8 & 12.1 \\
\hline & 秋 & 18 & 27.3 \\
\hline & 冬 & 2 & 3.0 \\
\hline \multirow{3}{*}{$\begin{array}{l}\text { 重 } \\
\text { 症 } \\
\text { 度 }\end{array}$} & 重 & 25 & 37.9 \\
\hline & 等 & 36 & 54.5 \\
\hline & 記 載 な し & 5 & 7.6 \\
\hline
\end{tabular}

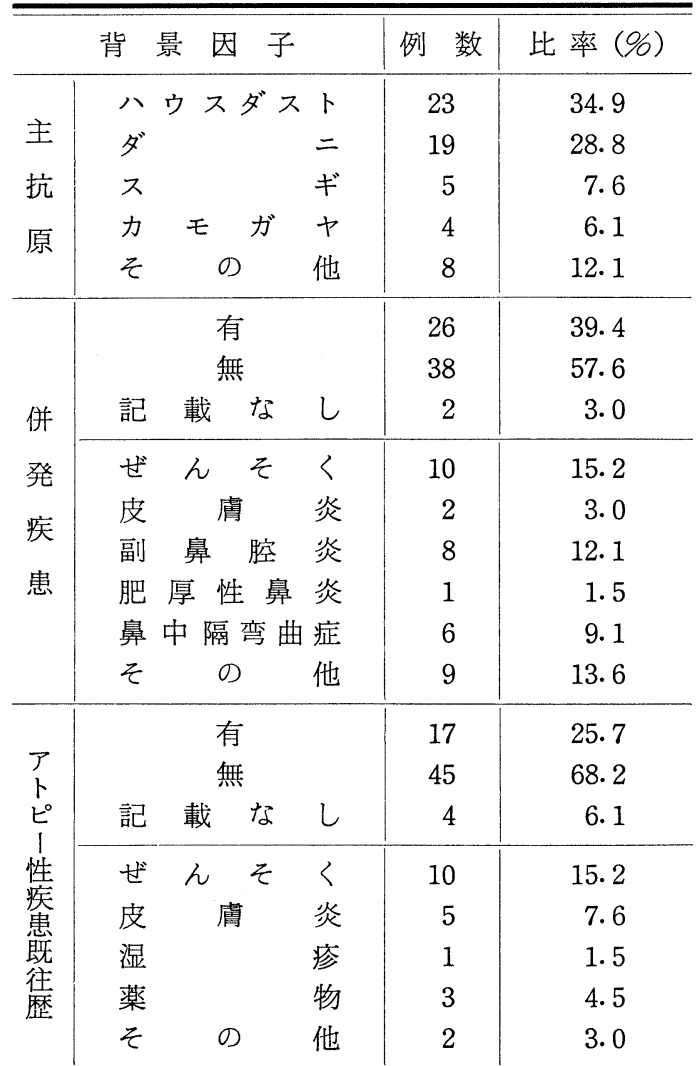


与後 3 週間目と 4 週間目では投与前との間に有 意差 $(\mathrm{p}<0.05,0.01)$ が認められた. 鼻閉スコ アは投与後しだいに減少し, 投与後 4 週間目で は投与前との間に有意差を認めた $(\mathrm{p}<0.05)$. すなわち，「くしゃみ」，「鼻汁」，「鼻閉」すべて の症状について統計学的に有意な改善が認めら れた。

表 5 総括判定結果

\begin{tabular}{|c|c|c|c|}
\hline & \multicolumn{2}{|c|}{ 判 定 時 期 } \\
\hline & & 2 週間目 & 4 週間目 \\
\hline \multicolumn{2}{|c|}{ 総 症 例 数 } & 66 & 66 \\
\hline \multirow{7}{*}{$\begin{array}{l}\text { 䚁 } \\
\text { 症 } \\
\text { 愍 } \\
\text { 善 }\end{array}$} & 著しく良い & 9 & 16 \\
\hline & い & 18 & 23 \\
\hline & やや良 い & 23 & 19 \\
\hline & 不 & 14 & 7 \\
\hline & 記 載 な し & 2 & 1 \\
\hline & 良い上上 & $40.9 \%$ & $59.1 \%$ \\
\hline & やや良い以上 & $75.8 \%$ & $87.9 \%$ \\
\hline \multirow{7}{*}{$\begin{array}{l}\text { 他 } \\
\text { 覚 } \\
\text { 的 } \\
\text { 䙿 } \\
\text { 改 } \\
\text { 曼 }\end{array}$} & 著しく良い & 4 & 11 \\
\hline & 良 & 20 & 23 \\
\hline & やや良 い & 15 & 15 \\
\hline & 不 & 23 & 16 \\
\hline & 記 載な し & 2 & 1 \\
\hline & 良い 以上 & $36.4 \%$ & $51.5 \%$ \\
\hline & やや良い以上 & $59.1 \%$ & $74.2 \%$ \\
\hline \multirow{7}{*}{$\begin{array}{l}\text { 全 } \\
\text { 般 } \\
\text { 改 } \\
\text { 善 } \\
\text { 度 }\end{array}$} & 著 明 改 善 & 11 & 20 \\
\hline & 中 等 度 改善 & 17 & 16 \\
\hline & 軽 度 改 善 & 24 & 23 \\
\hline & 無 & 12 & 5 \\
\hline & 記 載 な し & 2 & 2 \\
\hline & 中等度改善以上 & $42.4 \%$ & $54.5 \%$ \\
\hline & 軽度改善以上 & $78.8 \%$ & $89.4 \%$ \\
\hline \multirow{3}{*}{ 有 } & きわめて有用 & 11 & 17 \\
\hline & & 14 & 21 \\
\hline & やや有 用 & 27 & 22 \\
\hline \multirow{2}{*}{ 用 } & 無 & 11 & 5 \\
\hline & 記 載 な し & 3 & 1 \\
\hline \multirow[t]{2}{*}{ 度 } & 有 用以上 & $37.9 \%$ & $37.6 \%$ \\
\hline & やや有用以上 & $78.8 \%$ & $90.9 \%$ \\
\hline
\end{tabular}
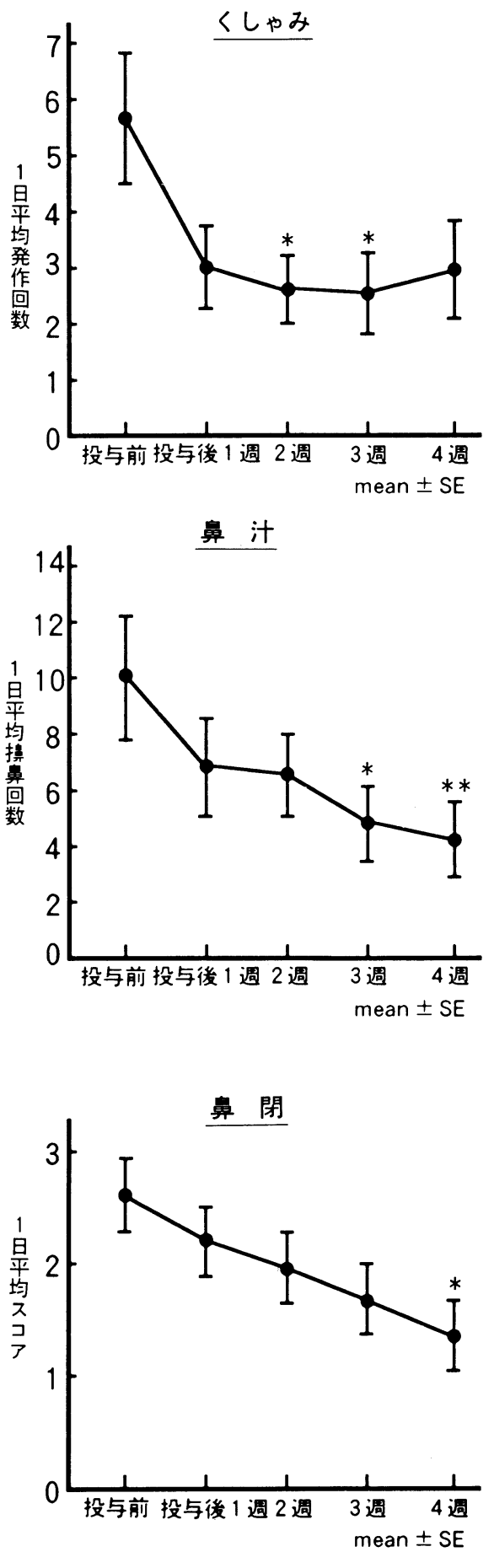

$(*: \mathrm{p}<0.05, * *: \mathrm{p}<0.01)$

図 3 鼻アレルギー日記における自覚症状の推移 


\section{考察}

鼻アレルギーに対する治療薬剤の主たる作用 機序としては, IgE 抗体産生の抑制, 抗原・抗 体反応によって起こるケミカルメディエーター 遊離の抑制，あるいはそれらによる種々の組織 反応の抑制の三つの作用点が想定されている22. 一方，特異的 $\mathrm{IgE}$ 抗体産生を抑制するととは 現在非常に困難であるとされ従来加ら開発され て来た鼻アレルギー治療薬剤のほとんどは，そ れ以外の作用機序のうちいずれか，あるいは両 者の作用機序を併有しているといわれる.今回 我々が主としてその効果について調査検討した 塩酸アゼラスチンも，乙れらの作用機序を有し 比較的広範な薬理作用をもつ鼻アレルギー治療 薬剤であるととが知られている。

アレルギー反応の場における塩酸アゼラスチ ンの薬理作用は，大別すると次に述べるような あのを挙げることがでさる。すなわち好塩基性 細胞からのヒスタミン遊離抑制および拮抗作 用 ${ }^{3)}$ ７)，ロイコトリエンの産生・遊離抑制作用 および拮抗作用 ${ }^{8) 9}$ ，抗血小板活性化因子(PAF)

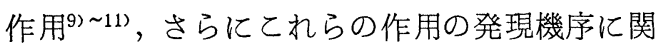
連して,カルシウムの細胞内流入阻害作用 ${ }^{3)}$ 12) 13) や，5-リポキシゲナーゼ阻害作用 ${ }^{81}$, 細胞内 c-AMP の上昇作用 ${ }^{14)}$ ，および細胞膜安定化作 用 ${ }^{14)}{ }^{15)}$ な゙現在までに多数の抗アレルギー作用 が報告されて来た，従って塩酸アゼラスチンの 臨床応用における抗アレルギー作用は以上のよ うな多彩な効果が互いに相剰して発揮されてい るあのと推定される。

本調査における 2 週間後，4週間後の臨床効 果は表 5 に示すような結果となった。奥田な (゙16) 22) の報告によると, 全般改善度70～90\%， 有用度69～90\%，自覚症状改善度66～90\%，他 覚的所見改善度 51 ～80\%という結果であり，乙 れは対象，実験方法などが異なるため同列に論 じることはできないが，我々の結果と近似する 值であり極めて高い臨床効果が認められた。 ま た，担当医による総括判定から得た結果の集計 から屯他覚的所見の改善にくらべ自覚症状の改
善が特に優れている。一方，その他の抗アレル ギー剂，例えばフマル酸ケトチフェン ${ }^{23) ， オ キ ~}$ サトミド24), トラニラスト ${ }^{25)}$, アンレキサノク $ス^{26)}$ などの効果と比較しても我々の得た調査 結果は優るとも劣らない有効率を示した.

本調査では使用薬剂に対するプラセボ薬剂を 使用していないが，奥田ら ${ }^{18)}$ の報告による塩酸 アゼラスチンとプラセボとの二重盲検試験にお ける内服プラセボの有効率 $41.3 \%$ からプラセボ 効果を推定すると, 十分にプラセボとは有意に 優れた有効性が得られていると推定された。

本調査における鼻アレルギー日記から算定し た結果から，塩酸アゼラスチンは「くしゃみ」, 「鼻汁」，「鼻閉」すべての症状に対し奏効し改 善しているととが認められた. 従来の報告では， 「くしゃみ」，「鼻汁」の改善には優れているが, 「鼻閉」の改善は劣るとしたものが多いが(6) 18)21)，乙の理由として非発作時における持続的 な鼻閉は鼻粘膜とくに甲介粘膜の不可逆的な結 合織の変性増殖や，局所自律神経の長期的異常 などによる肥厚により生じたものであり，抗ア レルギー剂はこの点に関しては奏功しないので はないかと考えられて来た ${ }^{16)}$.しかしながら， 我々の調査では長期使用において「鼻閉」にも 同様に改善が認められたととは特記すべきとと と考えられる。

塩酸アゼラスチンはアレルギー反応に対し広 範な薬理作用を有することが知られている。す なわちヒスタミンのみならずロイコトリエン， 血小板活性化因子 (PAF) などにも関与する。 ヒスタミンは粘膜固有層の血管壁を直接刺激し て循環障害をひきおとし，乙れが鼻閉の原因と なり27)，ロイコトリエン $\mathrm{D}_{4}$ および血小板活性 化因子 (PAF) あ鼻粘膜に直接作用することに より鼻粘膜腫脹をおこすととが知られている28 29). また，鼻粘膜の腫脹を来す作用効果につい て比較すると, ロイコトリエン $\mathrm{D}_{4}$, 血小板活 性化因子 (PAF)，ヒスタミンの順に強いといわ れている ${ }^{29)}$ 30). 塩酸アゼラスチンは，とのよう に鼻閉の原因よなるイコトリエン，血小板活 
性化因子 $(\mathrm{PAF})$, ヒスタミンに対して直接拮抗 作用を持ち，ロイコトリエンについては産生遊 離抑制作用，ヒスタミンについては遊離抑制作 用を持っているので，乙のような多彩な作用機 序を有するために「鼻閉」を軽減したものとあ いえよう。

以上，我々の今回の調査結果から塩酸アゼラ スチンは問題となるような副作用を特に有さ ず，鼻アレルギーの三主徴である「くしゃみ」, 「鼻汁」，「鼻閉」のいずれに扔いても効果を示 す有用な薬剤であることがわかった。

\section{結語}

66例の通年性鼻アレルギー患者に対して塩酸 アゼラスチンを投与し以下の結果を得た.

1）全般改善度は，投与後 2 週間目で，中等 度改善以上 $42.4 \%$ ，軽度改善以上 $78.8 \%$ ，投与 後 4 週間目で，中等度改善以上 $54.5 \%$ ，軽度改 善以上 $89.4 \%$ であった。

2) 有用度は，投与後 2 週間目で，有用以上 $37.9 \%$ ，やや有用以上 $78.8 \%$ ，投与後 4 週間目 で，有用以上 $37.6 \%$ ，やや有用以上 $90.9 \%$ であ った。

3）鼻アレルギー日記における自覚症状の推 移では，「くしゃみ」，「鼻汁」，「鼻閉」すべてに 統計学的に有意な改善が認められた.

4) 全症例中，副作用を認めたものはなか った.

以上の結果から塩酸アゼラスチンは通年性鼻 アレルギーに対し優れた臨床効果が期待できる 有用な薬剤であると考えられた。

本論文の要旨は第14回日耳鼻中国地方部会連合講演 会にてロ演発表した。

\section{参考文献}

1）奥田 稔：治療方針のたて方．鼻アレルギー診療 の実際（奥田 榆編). 179 188頁，金原出版， 東京, 1979.

2 ）江田昭英, 永井博式：抗アレルギー剂。薬局 30: 281 287, 1979 .

3 ) Chand N, Pillar J, Diamantis W, et al : Inhibition of calcium ionophore (A23187)-stimulated histamine release from rat peritoneal mast cells by azelastine; inplications for its mode of action. Europ J Pharmacol 96: 227 233, 1983.

4) Tasaka $K$ and Akagi $M$ : Anti-allergic properties of a new histamine antagonist, 4-(p-chlorobenzyl)-2-[N-methyl-perhydroxyazepinyl-(4)]-1-(2H)phthalazinone hydrochloride. Arzneim Forsh/ Drug Res 29 (I) : 3; 488 493, 1979.

5 ) Zechel HJ, Brock N, Lenke D, et al : Pharmacological and toxicological properties of azelastine, a novel antiallergic agent. Arzneim Forsh/Drug Res 31(II) : 8 ; 1184 1193, 1981.

6 ) Katayama $\mathrm{S}$, Akimoto $\mathrm{N}$, Shionoya $\mathrm{H}$, et al : Anti-allergic effect of azelastine hydrochloride on immediate type hypersensitivity reactions in vivo and in vitro. Arzneim Forsh/Drug Res 31(II) : $8 ; 1196 \sim 1203,1981$.

7) Yamanaka T, Shoji T, Murakami M, et al : Effects of azelastine hydrochloride, a new antiallergic drug, on the gastrointestinal tract. Arzneim Forsh/Drug Res 31(II) : $8 ; 1203 \sim 1206$, 1981.

8) 片山 敏, 角田 創, 佐久間義範, 他: Azelastine のロイコトリエン産生・遊離抑制作用およびロイ コトリエン拮抗作用. Prog Med 6 : 1173〜1178, 1986.

9 ）折笠悦子, 加藤義則, 田島鉄弥 : Azelastine の口 イコトリエン拮抗作用および PAF 誘発気道収縮 抑制作用. Prog Med $7: 2031 \sim 2036,1987$.

10）小杉忠誠，中村真理子，仲吉博彦，他：鼻アレル ギーにおける血小板機能の意義 1 . アレルギー 性鼻炎患者における Azeptin 投与前後の血液凝 固線溶血小板機能の推移. 耳鼻 $33: 852 \sim 858$, 1987.

11）藤森 徹, 原田耕吉 : Azelastine のヒト血小板に おける抗 Platelet activating factor (PAF) 作用. 診と薬 $23: 2251 \sim 2253,1986$.

12）高中紘一郎：アゼラスチンの多形核白血球に及ぼ す影響一アラキドン酸カスケード阻害機構一。 Prog Med 7 :275 278, 1987.

13）洲崎悦子, 昇 公一, 小林純郎, 他: モルモット 多形核白血球の刺激応答反応に対する Azelastine の阻害作用. 診断之治療 75 :2551 2556, 1987. 
14）赤木正明, 見尾光庸, 田坂賢二, 他: Azelastine のHistamine 遊離抑制機序. 応用薬理 $26: 191 \sim$ 198, 1983.

15）洲崎悦子，洲崎敏伸，昇 公一, 他：赤血球の構 造と機能に対する Azelastine の作用. Prog Med $7:$ 1325 1330, 1987.

16）奥田 稔, 馬場俊吉, 堤 昌巳, 他: 鼻アレルギ 一に対する E-0659の臨床成績. 耳展 23 補 6 ： $441 \sim 461,1980$.

17）奥田 稔, 古内一郎, 堤 昌巳, 他: 通年性鼻了 レルギーに対する E-0659, Disodium Cromoglicate，およびプラセボとの二重盲検法による臨床 的検討. 耳展 26 補 $6: 563 \sim 604,1983$.

18）奥田 稔, 石井哲夫, 古内一郎, 他 : 経口抗アレ ルギー剂 E-0659 (azelastine hydrochloride) の鼻 アレルギーに対する臨床的検討一placebo との二 重盲検群間比較試験一.耳展 26 補 $6: 606 \sim 645$, 1983.

19）高坂知節, 郭 安雄, 河本和友, 他 : 鼻アレルギ 一に対する E-0659 (Azelastine) の長期投与にお ける臨床的検討. 耳鼻 $29: 634 \sim 650,1983$.

20）榎本和子, 荒ひろみ, 砂金秀充, 他：鼻アレルギ 一に対するE-0659の使用経験. 臨床之研究 60 : 3114 3122, 1983.

21）奥出芳博, 矢島 洋, 海野徳二：小児の通年性鼻 アレルギーに対する E-0659(azelastine hydrochloride) 顆粒の臨床成績の検討. 臨床と研究 61 : 1341 1346, 1984.

22）大迫茂人：鼻アレルギーに対する E-0659 (Azeptin ${ }^{\circledR}$ ) の高用量での臨床使用成績. 診と薬 $20: 1005 \sim 1014,1983$.

23）奥田 稔, 大塚博邦, 福田 諭, 他：通年性鼻 アレルギーに対する HC 20-511 (Ketotifen) と
Clemastine fumarate との二重盲検比較試験によ る臨床的検討. 耳展 26 補 $4: 347 \sim 384,1983$.

24）奥田 稔, 形浦昭克, 榎本和子, 他 : 鼻アレルギ 一に対する抗アレルギー剤KW-4354(Oxatomide) の臨床的検討 (二重盲検試験). 耳展 27 補 $3: 386$ $\sim 405,1984$.

25）奥田 稔, 石川 哮, 斎藤洋三, 他 : 通年性鼻了 レルギーに対する N-5' の臨床評価一多施設群間 比較二重盲検法による検討一. 耳展 26 補 3 : $211 \sim 250,1983$.

26）奥田 稔, 海野徳二, 川堀真一，他：アレルギー 性鼻炎に対する AA-673 錠の臨床評価一トラニラ ストカプセルとの二重盲検比較対照試験一.耳展 31 補 $3: 281 \sim 307,1988$.

27）奥田 稔, 坂口幸作, 大塚博邦：鼻のアレルギ 一. 臨床医 $9: 567 \sim 570,1983$.

28）寺田修久, 今野昭義, 安藤英樹, 他 : 鼻アレルギ 一とロイコトリエン（第 1 報）誘発鼻汁中からの ロイコトリエンの抽出，测定および鼻粘膜に対す るロイコトリエン $\mathrm{C}_{4}, \mathrm{D}_{4}$ の作用について. 日耳 鼻 $90: 1196 \sim 1207,1987$.

29）今野昭義, 寺田修久, 安藤英樹, 他 : 鼻粘膜腫脹, 鼻粘膜過敏性に与える血小板活性化因子(PAF) の 影響について. 耳鼻免疫アレルギー $5: 2 ; 24$ 25, 1987.

30）今野昭義：微小循環における血管と白血球の反応 part 2 鼻アレルギーにおける鼻過敏症状の発症機 序. 炎症 $8: 2 ; 103 \sim 114,1988$.

(原稿採択 : 平成元年 2 月 3 日 急載) 別刷請求先 : 前田 学

T700 岡山市鹿田町2-5-1

岡山大学医学部耳鼻咽喉科学教室 